\title{
Paideusis
}

\section{A Career in Philosophy of Education}

\section{Jerrold Coombs}

Volume 19, Number 2, 2010

URI: https://id.erudit.org/iderudit/1071921ar

DOI: https://doi.org/10.7202/1071921ar

See table of contents

Publisher(s)

Canadian Philosophy of Education Society

ISSN

0838-4517 (print)

1916-0348 (digital)

Explore this journal

Cite this document

Coombs, J. (2010). A Career in Philosophy of Education. Paideusis, 19(2), 54-60.

https://doi.org/10.7202/1071921ar

(C) Jerrold Coombs, 2010

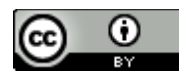

This document is protected by copyright law. Use of the services of Erudit (including reproduction) is subject to its terms and conditions, which can be viewed online.

https://apropos.erudit.org/en/users/policy-on-use/
This article is disseminated and preserved by Érudit.

Érudit is a non-profit inter-university consortium of the Université de Montréal, Université Laval, and the Université du Québec à Montréal. Its mission is to promote and disseminate research.

https://www.erudit.org/en/ 


\title{
A Career in Philosophy of Education
}

\author{
JERROLD COOMBS \\ University of British Columbia
}

Except for a penchant for arguing, nothing in my early life foreshadowed my becoming a philosopher of education. Although our household had many books on history, psychology, and literature, there were none on philosophy. However, political debate was a prominent feature of our dinner table conversation, at least from the time I was in junior high school. When I entered senior high school, I joined the inter-scholastic debating team, primarily because it got me out of taking the standard English literature class. Not only did I thoroughly enjoy presenting arguments, I also learned quite a bit about constructing and refuting them. Perhaps there was a little of the philosopher in me even at that time, for I well remember an impromptu argument with a friend that only a philosopher could enjoy-an argument about whether or not nothing exists. Where was Wittgenstein when I needed him?

\section{First Steps}

When I began undergraduate studies at Kent State University in the fall of 1954, I planned to become a history and English teacher. To fulfill part of the general education requirement of the University, I chose to take an introduction to philosophy course. Joseph Politella, my instructor, was a very gentle man with a passion for both philosophy and teaching. Several weeks into the course, he invited me and several other students to his home one evening a week to discuss philosophy, which we did while eating cookies and sipping Constant Comment tea. These evening meetings, which covered a wide range of topics, continued throughout my undergraduate years. Professor Politella's course captured my interest as no previous course had done, leading me eventually to take all the courses required of students majoring in philosophy. Assuming that a degree in philosophy would be of little or no help in getting a job, I continued the courses required for my degree in education rather than transferring into the philosophy department. Eventually, I decided, with the encouragement of my philosophy professors, to pursue graduate studies in philosophy.

My career path took another unexpected turn when, shortly before the end of my undergraduate studies, I received a visit from Paul Komisar from whom I had taken a course in educational foundations as part of my teacher education program. He persuaded me to take a master's degree in philosophy of education-in part, by offering me financial assistance in the form of a graduate teaching assistantship, which I badly needed if I was to pursue graduate studies. Loathe as I was to leave philosophy proper, I had been very impressed with the philosophical aspects of Professor Komisar's course. Moreover, this seemed the perfect way to wed my interest in education with my passion for philosophy.

(C) Copyright 2010. The author, Jerrold Coombs, assigns to Paideusis the right of first publication and educational and non-profit institutions a non-exclusive license to use this document for personal use and in courses of instruction provided that the article is used in full and this copyright statement is reproduced. Any other usage is probibited without the express permission of the author. 


\section{Graduate Studies}

As part of my masters program, I took an individual study course with Professor Komisar in which he introduced me to the work of analytic philosophers such as Ludwig Wittgenstein, J.L. Austin, Gilbert Ryle and J.O. Urmson. These works were a revelation to me because none of my undergraduate philosophy courses had made any mention of these philosophers or of British analytic philosophy in general. As it turned out, the works of Wittgenstein and Austin were very influential in the development of my thinking. I was much taken by Wittgenstein's view that the traditional philosophical puzzles I had been studying as an undergraduate were simply confusions occasioned by taking words out of the contexts of the language games from which they gained their sense. However, I never really bought into the idea that philosophy's only task was, as Wittgenstein put it, to get the fly out of the fly bottle. Austin's work impressed upon me the fruitfulness of carefully investigating the distinctions built into our ordinary language as a first step in understanding our more theoretical conceptual problems. Taken together, these philosophers convinced me that at least one purpose in doing philosophy was to attempt to resolve problems by carefully examining the meaning and use of the language in terms of which we think about them. Moreover, after studying Wittgenstein and Austin, I began to see philosophy, not simply as a set of theories about a particular set of problems, but as a unique kind of conceptual, intellectual inquiry. Consequently, when I embarked on my master's thesis, I chose to try to illuminate then current arguments about equal educational opportunity, by analyzing how the phrase "equal educational opportunity" was used in educational debates.

Having finished my master's degree, I followed Paul Komisar's recommendation and applied to pursue doctoral studies at the University of Illinois where he had taken his graduate work. While studying for my Ph.D. at the University of Illinois in the early 1960s, I inhabited two different academic worlds. Although they were quite happy to indulge my interest in analytic philosophy, none of the philosophy of education professors had any background or interest in that approach to philosophical inquiry. They and the courses I was required to take focused on educational theories, theories of social change, and the works of John Dewey. In addition, all doctoral students were required to take core courses in history of education and educational psychology as well as learning to read two foreign languages. Much of what I learned from my educational courses became important to my work, particularly those on John Dewey with Professor Joe Burnett. Nonetheless, my studies in the philosophy department, which was largely staffed with analytic philosophers, held greater interest for me and had a greater impact on my future work.

Several aspects of my study at Illinois made the bifurcated academic landscape more tolerable. By tradition, a graduate student run departmental seminar met bi-weekly in the home of a student. At these seminars, which were only sometimes attended by a faculty member, students took turns reading and getting responses to their papers. These gatherings, where we discussed philosophy over beer and chips, were as much social as they were academic affairs. Not only did I receive useful feedback on my analytical work, I developed many close friendships.

Another factor that enhanced my academic experience was being able to attend several Philosophy of Education conferences each year to meet and discuss ideas with like-minded philosophers of education such as Tom Green, Bob Ennis, Jim McClellan, and Paul Komisar. Even here, however, there was a schism between the older philosophers of education, and the younger, analytically-oriented ones. Nor was there much tolerance between these groups. Analytic philosophers, complaining that they were unfairly excluded from the program, sometimes held their own sessions independently from the official program, advertised only by word of mouth.

When I began my doctoral studies, I was assigned to work as a research assistant to B. Othanel Smith, whose research team was half way through a four-year project devoted to studying logical operations in teaching. Although I never took a course with Professor Smith, my work with him had more influence on my future career than any other aspect of my graduate studies. While not an analytic 
philosopher himself, he was familiar with standard works in the field and appreciated the contribution such a philosophical approach could bring to the sort of empirical study in which he was engaged. Working with him contributed to my academic development in several ways. First, because he was an empirical researcher with a keen appreciation of the importance of conceptual clarity, I gained a sense of the value of bringing together empirical and conceptual research. Second, by treating me as a colleague rather than an employee-giving me important tasks and allowing me to pursue them in the way I thought best, he provided a model of collaborative research I tried to emulate with my own graduate students. Finally, working on Professor Smith's projects eventually led me to two enduring lines of inquiry in my professional work: the logic of concept teaching and the nature of value reasoning. I became so invested in this work that I stayed on as a research professor for one year after obtaining my degree.

\section{The Nature of My Work}

The point of philosophy of education of the sort I practice is to improve the conceptual apparatus or conceptual resources that may be brought to bear on educational problems and issues. Since I believe that any improvement in educational policy or practice must start, basically, from our current shared commitments and ideals, I never gave credence to the notion that philosophers of education should construct grand educational theories or attempt to derive educational policies from philosophical theories. Accordingly, my general approach to philosophy is problem centered. Usually it begins with the suspicion that some theory, line of argument, or research is based on inadequate or confused conceptualizations and needs to be rethought. This sort of approach, which for brevity I will call the conception reconstruction approach (CRA), usually involves an analysis of the major concepts involved in framing the practice, theory, or research program, as well analysis of the arguments given in support of current interpretations of them. Such analyses investigate the meaning and use of terms both in ordinary discourse and in the context of the theory in which they play a role. CRA also may involve proposing and defending a particular interpretation of a disputed concept by showing that it is more fruitful or better grounded in shared, fundamental values than its competitors.

My work tends to have focused on conceptions of educational outcomes such as critical thinking, practical reasoning, multicultural education, global education, respect for the rule of law, and so on. Often, inquiries concerning educational goals have drawn me into related inquiries on educational means. For example, consideration of the goal of morally educating persons prompted me to consider the concepts of indoctrination and rational persuasion. Of course, conceptions of educational goals are very often normative. The phrases "critical thinking" and "practical reasoning", when used to refer to educational goals, are understood to be referring to good thinking or reasoning. Consequently, a CRA inquiry into such goal conceptions involves attempting to determine what epistemic standards the reasoning has to meet to count as good reasoning, and what intellectual resources students need to acquire if they are to fulfill these standards.

There are several benefits to this approach to philosophy of education. Perhaps the most important is that one's work may, because it is problem focused, actually persuade educational decisionmakers to rethink their conceptualizations. This is not to say decision-makers will welcome such philosophical examinations. Usually they will not, for philosophy of this sort tends to be critical of prevailing conceptions and theories. A lesser, but still important benefit, is the transparency of this approach. If the study is well done, the published results should make manifest the grounds on which one's conclusions rest and, therefore, the grounds on which they may be challenged.

One limitation of the CRA approach is that it does not require the philosopher using it to take due account of the fact that certain ways of conceptualizing educational issues and problems advantage some groups, usually the dominant groups in society, and disadvantage others. A philosopher who uses the CRA approach without taking adequate account of the political import of the conception at issue, 
may, without meaning to, contribute to the perpetuation of injustice. This limitation is, I believe, easily overcome, for there is nothing in the CRA approach that requires or encourages practitioners to ignore the political implications of the constructs they criticize or defend, or to be unconcerned about the possibility of bias due to one's own background.

There is, however, an important sense in which this approach is conservative-it accepts the more important and fundamental values of our society as the starting point for its arguments. Since philosophy of any sort relies on rational persuasion to bring about changes in public or educational policy, it must, of necessity, appeal to basic values already held by those it seeks to persuade. One who seeks changes that cannot be brought about by rational persuasion should become a revolutionary, not a philosopher. Progressivism is possible because in any given problematic situation a fundamental conception that has been given a conservative interpretation may itself be subject to reinterpretation in light of other basic values. Thus, the CRA approach to philosophy need not be, and likely will not be, politically conservative except when practiced by a philosopher who is politically conservative.

It is worth commenting on one further alleged limitation of approaches such as CRA. It has been argued that these sorts of analytic approaches pretend to an objectivity they cannot possibly attain - that because the meanings of terms differ from person to person and group to group the conclusions the CRA approach derives will, necessarily, be partial to the group of which the inquirer is a member. I believe this view greatly exaggerates the variability of the meaning and use of terms within a language community. True enough, one's conclusions about meaning can be coloured by one's social location, but I see no reason to believe this must be the case. A competent analysis will advance only those conclusions that are warranted by the linguistic intuitions of diverse language users. More importantly, this criticism misunderstands the essential nature of the CRA approach. It does not aim to discover universal truths but, rather, to make responsible contributions to ongoing public conversations about educational policy and practice. Both conclusions of analysis and their supporting arguments are submitted to public scrutiny, allowing other participants in the public dialogue with other backgrounds and other experiences to criticize, amend, or rebut the conclusions. Individuals may strive for as much objectivity as they can acquire, but it is the public dialogue that ultimately drives one's conclusions toward objectivity. The drive toward objectivity can, of course, be thwarted if important constituencies have no opportunity to participate in the dialogue.

Perhaps the most important limitation of the analytic approach is that it provides no overall theory of education that can serve as a rallying point for educational reformers in the way John Dewey's theory did. It requires philosophy of education of a rather different sort to provide a vision of what the best possible educational system might look like.

\section{Facilitators}

From the beginning of my work at the University of British Columbia (UBC), I was fortunate in having excellent colleagues and graduate students with whom to discuss philosophy of education. LeRoi Daniels, in particular, played an important role in furthering my work. I do not recall now whose idea it was to form the Association for Values Education Research, but there is no doubt that Roi was the spark plug that kept it going. For many years, members of this group were the primary sounding board for my ideas about practical reasoning and moral education, disabusing me of many a bad argument before I could make it public. Roi was also responsible for roping me into projects I might otherwise not have contemplated-like teaching critical thinking in prison. Having funding to attend Philosophy of Education conferences also played an important role in helping me keep abreast of the various kinds of work going on in the field, and in allowing me to discuss my research with others doing similar kinds of work or working in the same general area.

The only institutional factor that hindered my work was the compartmentalization of faculty members that restricted intellectual interchange with both philosopher and non-philosopher colleagues. 
When I first began to teach at UBC, most of the education faculty members had lunch in the faculty lounge, and many of them often took coffee breaks there, too. The discussions I had during these times kept me abreast of the latest theories in education. Since I regarded critique of such theories as part of my gadfly function, these lunchtime discussions were invaluable. Unfortunately, after a few years, the food service was withdrawn and the lounge fell into disuse. Later still, our department was relocated away from other departments in the faculty-further inhibiting interdepartmental communication. At the same time, I found it difficult to get to know and share ideas with my colleagues in the philosophy department. Although I regularly attended their departmental seminars and visiting lectures, it took nearly ten years before we had genuinely collegial discussions.

\section{Foci of My Work}

One problem central to my work concerned the rationality of practical judgments. Working on Bunnie Smith's logic in teaching projects, I became involved in analyzing classroom discussions wherein students made and defended value judgments. It seemed to me that such discussions would be pointless unless they were informed by standards of good or rational judgment. Moreover, I believed that teachers should not expect their students to accept or adopt value judgments or principles unless they were rationally justified. To deny this was, in my view, to open the door to indoctrination. Thus, an important thread in my work was attempting to identify, describe, and justify certain standards as those that must be met if a value judgment is to be justified. And, since morality is learned before rationality is fully developed, it also led me to consider how and to what extent morals might be rationally taught. Eventually, the quest to answer these questions led me to examine the notion of rationality itself and the extent to which it can be explicated independently of cultural norms and the particular realms of life in which it may be exhibited.

A second major problem that had a central place in my work was the nature of concept learning. This problem, too, arose from my analysis of classroom discussions in which concepts were taught. Reading transcripts of these discussions convinced me that the regnant theories of concept formation being advanced by psychologists were mistaken. These theories, which focused on manipulating positive and negative instances of a concept, entirely missed Wittgenstein's insight that concepts are learned by learning the language games of which they are part. Consequently, they were much too simplistic. I attempted to identify the various kinds of information students might be given in a classroom to enable them to learn a concept, and the extent to which different kinds of concepts required different sorts of information.

While studying for my master's degree, I wrote a paper on the concept of critical thinking, and have returned to the topic many times since. My work on practical reasoning can reasonably be seen as an attempt to describe what would count as critical thinking about values. But I guess this concept finally became a focus of concern because so much nonsense was being written about it - some of it due to a misunderstanding of John Dewey's discussion of problem solving, but much more of it due to the pernicious misreading of Bloom's taxonomy of cognitive educational objectives whereby Bloom's categories of objectives were transmuted into critical thinking "skills."

My interest in explicating the concept of equal educational opportunity, which began with my master's thesis endured throughout my career. I was continually drawn back to it both because of a strong commitment to equality and because of the enormous interest philosophers took in it after the publication of Rawls' A Theory of Justice. Given that we can't ensure equal educational outcomes, and given that differences in talents and interests make the education suitable for some unsuitable for others, how can we make a good case that there is or is not equal educational opportunity in any given instance? That was the question that intrigued me. 


\section{Evolution of My Work}

There were no dramatic changes in the direction of my work over the course of my career. Rather, my views evolved gradually in response to reactions to my work, the limitations I perceived in my previous work, and the work of other philosophers investigating similar or related issues. In the early days of my career, my work focused almost exclusively on analysis and critique, while in later years, I spent more time developing and defending particular conceptions of educational aims such as critical thinking, legal reasoning, moral education, multicultural education, and respect for the rule of law.

Over time, there was also a subtle but significant change in the way I viewed the tasks of moral education and educating for critical thinking. I began to appreciate more fully that moral reasoning and critical thinking are aspects of more complex intellectual and social practices. Since the standards of rationality I sought to elucidate are standards abstracted from the practices of morality and scienceparticularly the norms of criticism and revision built into these practices, I began to take a broader look at what these practices involved in the way of practical deliberation and what intellectual resources they require. With regard to moral education, this led me to pay much more attention to the role that moral concepts play in moral judgment and how moral concepts can be responsibly modified to apply to new cases they had not previously encompassed. In part, this shift was due to my study of legal reasoning and the similarities I perceived between the tasks of legal and moral reasoners, as well as between the intellectual resources available for each sort of judgment. This shift was accompanied by a shift in how I viewed the task of moral education. No longer was it as a matter of directly teaching standards of good moral reasoning, but more a matter of helping students who had already been initiated into the practice of morality to become more rational and responsible participants in this practice. One result of this shift was my giving increased attention to devising educational, non-indoctrinatory means of helping students' improve their store of moral concepts through rationally reflecting on their range of application and the point they serve.

\section{Retrospective}

Having been retired for nearly ten years, I am only vaguely acquainted with current trends in philosophy of education. In general, works in philosophy of education appear to be more overtly political, in the sense that they self-consciously attempt to further some policy or program such as feminism, environmentalism, or anti-colonialism. In the later years of my career, work in the field seemed to become somewhat eclectic to the point that some works in philosophy of education appeared to shade into sociology or autobiography. Some philosophers have focused on analyzing conceptions of educational issues to determine whose interests are served by them, and who is disadvantaged by them. Thus, they produce works that seem as much sociological as philosophical. Others, suspicious of the possibility of anyone's reaching objective conclusions having authority beyond their own reference group, have taken pains to describe their own background and point of view - presumably to give their readers a better basis for deciding what to make of their work. These are no doubt salutary additions to the philosopher's stock in trade, but I worry that in the zeal to take up good causes, careful analysis and reconstruction of educational concepts aimed at increasing their clarity and fruitfulness may be slighted.

A further trend that appeared toward the end of my career at UBC was the gradual erosion of institutional support for philosophy of education, together with a concomitant diminution of the philosophical background required of persons seeking positions in philosophy of education. One can only hope that the pendulum will eventually swing back, and philosophy of education will regain some of the support it previously enjoyed. 


\section{Works That Have Significantly Influenced My Thinking}

Aristotle. "Nichomachean Ethics." Ed. Jonathon Barnes. The Complete Works of Aristotle. Princeton, NJ: Princeton University Press, 1984.

Austin, J.L. Philosophical Papers. Oxford: Clarendon Press, 1961.

Dworkin, Ronald. Taking Rights Seriously. Cambridge, MA: Harvard University Press, 1977.

Hare, R.M. Freedom and Reason. New York: Oxford University Press, 1965.

Kant, Immanuel. Foundations of the Metaphysics of Morals, and What Is Enlightenment? Trans. Lewis White Beck. New York: Liberal Arts Press, 1959.

Kohlberg, Lawrence. The Psychology of Moral Development: The Nature and Validity of Moral Stages. San Francisco: Harper and Row, 1984.

Lakatos, Imre. "Falsification and the Methodology of Scientific Research Programs." Eds. I. Lakatos and A. Musgrave. Criticism and the Growth of Knowledge. Cambridge: Cambridge University Press, 1970.

Putnam, Hilary. Reason, Truth and History. Cambridge: Cambridge University Press, 1981.

Rawls, John. A Theory of Justice. Cambridge, MA: Belknap Press of Harvard University Press, 1971.

Scheffler, Israel. Reason and Teaching. London: Routledge, 1973.

Wallace, James D. Moral Relevance and Moral Conflict. Ithaca, NY: Cornell University Press, 1988.

Wittgenstein, Ludwig. Philosophical Investigations. Oxford: Blackwell Publishing, 1953. 